\title{
Polymerization Shrinkage and Contraction Force of Composite Resin Restorative Inserted with "Megafiller"
}

\author{
Yoshiaki TANI, Toshiyuki NAMBU, Akiko ISHIKAWA ${ }^{1}$ and Shigeru KATSUYAMA ${ }^{1}$ \\ Department of Biomaterials, Research Center for Biomedical Engineering, Kyoto University, \\ 53 Kawahara-cho Shogoin, Sakyo-ku, Kyoto 606, Japan \\ ${ }^{1}$ Department of Operative Dentistry, School of Dentistry at Tokyo, Nippon Dental University, \\ 2-3-16 Fijimi, Chiyoda-ku, Tokyo 102, Japan
}

Received July 29, 1993/Accepted October 15, 1993

\begin{abstract}
This study quantified the contraction force and polymerization shrinkage of composite resins with / without $\beta$-Quartz Glass Ceramic Inserts (BQCI) as "Megafiller". The materials used for the determination included a chemically cured composite and five light-cured composites. The system for measuring contraction force consisted of a transparent teflon tube for preparing the specimen, a small load cell, a dynamic strain guage and a pen-recorder. After the composite was packed into the teflon mold, a BQCI (Type R3) was inserted through the opening and the specimen was cured. Linear polymerization shrinkage of the composites was measured every 10 seconds from the start of mixing or irradiation to 90 minutes by the mercury bath method. Three pieces each of BQCI (Type T3) were inserted in each specimen. The results suggested that BQCI was markedly effective in reducing polymerization shrinkage, but was not always effective in reducing the contraction force during polymerization.
\end{abstract}

Key words : Composites, Polymerization shrinkage, Glass inserts

\section{INTRODUCTION}

Composite resin restoratives require physical properties such as abrasion resistance and fracture toughness, long-term color stability, and adhesiveness to the tooth. The physical and optical properties have been markedly improved. However, composite resin restoratives themselves are not adhesive to the tooth, and a bonding agent at the interface between the tooth and the restorative is required. For long-term adhesiveness to the tooth, factors that inhibit adhesion should be eliminated in addition to improving the bonding agent. The major factors inhibiting adhesion include polymerization shrinkage and contraction stress during polymerization.

Polymerization shrinkage of composite resin is considered to be the primary cause of marginal gaps. In clinical practice, marginal adaptation of composite resin has been improved by the use of a bonding agent. However, when the contraction force associated with polymerization exceeds the adhesive force of composite resin to the tooth, gaps occur, and cavity sealing of the restoration is impaired. Ishikawa ${ }^{1)}$ reported a nagative correlation between the polymerization shrinkage rate and the filler content. In contrast, Tani ${ }^{2}$ reported there was no correlation between the contraction force of composite resin and the filler content. Bowen ${ }^{3-6)}$ proposed a new clinical technique by which coarse granules of $\beta$-Quartz Glass-Ceramic Insert (BQCI) as "Megafiller" are added to the composite resin paste packed 
in the tooth cavity. Therefore, we evaluated the effects of adding BQCI to composite resin on polymerization contraction force and the polymerization shrinkage rate.

\section{MATERIALS AND METHOD}

The materials used in this experiment included an auto polymerizing type and five photopolymerizing type resins (Table 1). The filler content of CF2 and RLX used for anterior teeth was 73-79 wt\%, and that of P-50 and CPP for posterior teeth was $84-85 \mathrm{wt} \%$. PEL and HMR for both anterior teeth and posterior teeth were submicron filler and microfiller types, respectively. $\beta$-Quartz Glass-Ceramic Inserts are available in three shapes ("R" round cylinder, " $T$ " tapered cylinder, " $L$ " shaped inlay) and three sizes (1, 2 and $3 \mathrm{~mm}$ in diameter). All of the megafillers were pretreated with a silane coupling agent and showed a slightly wet surface due to silane-treatment. A small knob for holding with tweezers juts out on each megafiller. The shape and size of the megafiller were selected according to the size of the test specimen (Fig. 1).

Measurement of contraction force during polymerization

We developed a device ${ }^{2)}$ that measured the contraction force during polymerization using a small load cell * (10 kg-both for tension and compression). The force was converted by a dynamic strain gauge **, serially measured and recorded by a pen recorder\# (Fig. 2). As shown in Fig. 3, at the packing site of composite resin, a teflon tube (inside diameter, $5 \mathrm{~mm}$; outside diameter, $6 \mathrm{~mm}$; length, $12 \mathrm{~mm}$ ) was inserted into a stainless tube (5 mm in diameter) as a guide. A slit ( $4 \mathrm{~mm}$ ) had been made on the side of the transparent teflon tube, and the composite resin paste was inserted via the slit (Fig. 4).

To prevent adhesive fracture due to shrinkage during polymerization of resin, propeller

Table 1 Composite resin restoratives tested

\begin{tabular}{|c|c|c|}
\hline Code & Materials & $\begin{array}{l}\text { Shade and } \\
\text { Batch No. }\end{array}$ \\
\hline $\mathrm{CF} 2$ & Clearfil Fll ${ }^{\phi 1}$ & $\begin{array}{l}\text { F U - } 1498 \\
\text { F C - } 1399\end{array}$ \\
\hline RLX & Restolux SP-2 $2^{\phi 2}$ & $\mathrm{U} \quad 1154$ \\
\hline $\mathrm{P} 50$ & $\mathrm{P}-50^{\phi 3}$ & $\mathrm{U} \quad 1 \mathrm{ED} 4 \mathrm{R}$ \\
\hline $\mathrm{CPP}$ & Clearfil Photo Posterior ${ }^{\phi 1}$ & US $\quad 000002$ \\
\hline PEL & Palfique Estelite ${ }^{\phi 4}$ & U E U226 \\
\hline HMR & Heliomolar Radiopaque ${ }^{\star 5}$ & U $\quad 360407$ \\
\hline
\end{tabular}

ф1 Kuraray, Osaka, Japan

\$2 Lee Pharmaceuticals, South El Monte, CA, USA

ф3 $3 \mathrm{M}$, St. Paul, MN, USA

ф4 Tokuyama Soda, Tokyo, Japan

$₫ 5$ Vivadent, Schaan, Liechtenstein

* LU-10KSB34D, Kyowa Electronic Instruments Co., Tokyo, Japan

** Strain Amplifier DPM-611A, Kyowa Electronic Instruments Co., Tokyo, Japan

\# LR 4210, Yokogawa Electric Corp., Tokyo, Japan 


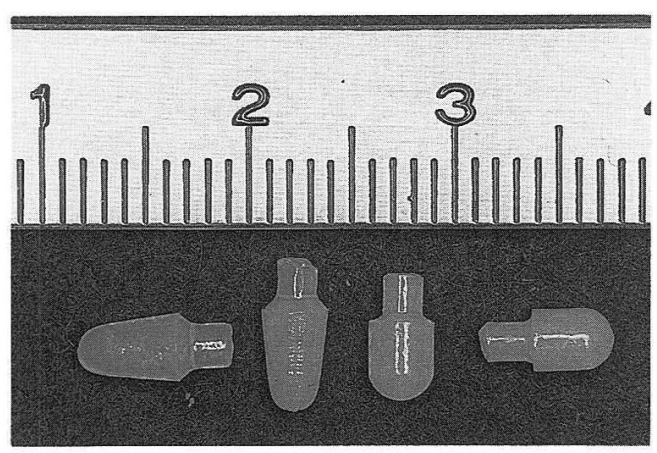

Fig. $1 \quad \beta$-Quartz Glass-Ceramic Inserts ${ }^{\circledR}$ used in this experiments. Type R3 for the contraction force measurement (right) and Type T3 for the polymerization shrinkage measurement (left).

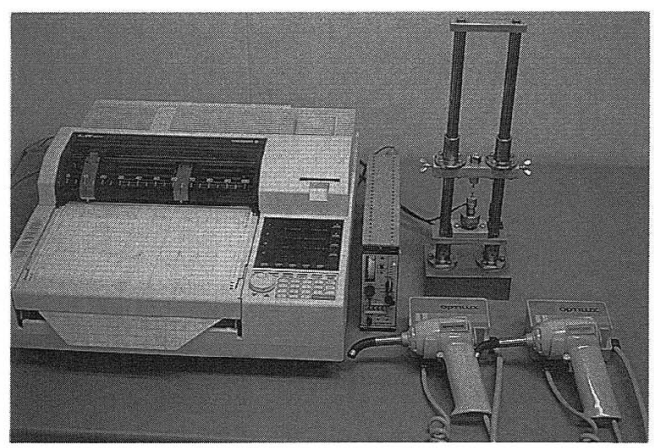

Fig. 2 Device for the measurement of the contraction force.

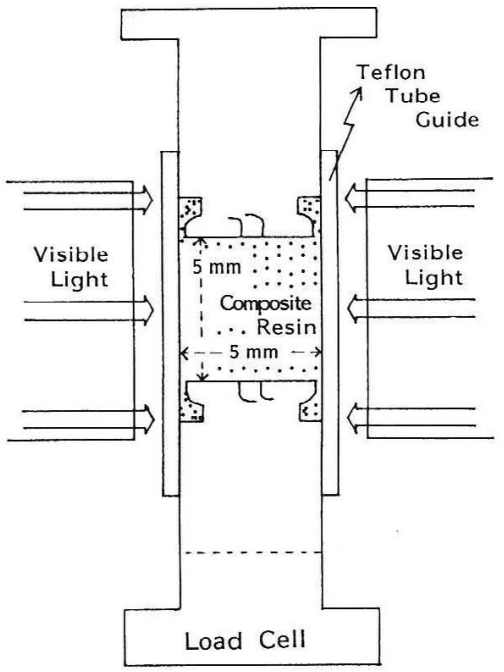

Fig. 3 Schematic illustration of the packing site of composite resins in the device.

-shaped stainless holders were applied to the upper and lower surfaces of the test specimen. The cylindrical composite resin specimen had a diameter of $5 \mathrm{~mm}$ and a length of $5 \mathrm{~mm}$. The autopolymerizing composite resin was inserted via the slit after 20-second mixing, and a BQCI\# (Type R3) (Fig. 1) was inserted into the resin. The time for inserting the composite resin and $\mathrm{BQCI}$ was within 1 minute and 40 seconds. Measurement started 2 minutes after the beginning of mixing and continued for 3 hours. The light-cured composite resin paste and BQCI were similarly inserted. Irradiation was performed using visible light sources ${ }^{\circledR}$

\# Lee Phamaceuticals, South El Monte, CA, USA

@ Optilux, Demetron Research Corp., Danbury, CT, USA 
from both sides for 60 seconds for polymerization. Measurement was started simultaneously with the beginning of light irradiation and continued for 3 hours. The volume of BQCI (Type R3) accounted for 15\% of the volume of the composite resin specimen. For comparison, measurement was also performed in composite resin specimens without a BQCI and those with a teflon piece ( $3 \mathrm{~mm}$ in diameter) with the same size and volume as that of the BQCI (Type R3). All measurements were performed in a room at a constant temperature of $20^{\circ} \mathrm{C}$ with a constant relative humidity of $50 \%$. The results are shown as the mean value of three measurements.

\section{Measurement of polymerization shrinkage}

Polymerization shrinkage was measured by the mercury bath method shown in Fig. 5. This procedure can be readily performed without restriction of the specimen.

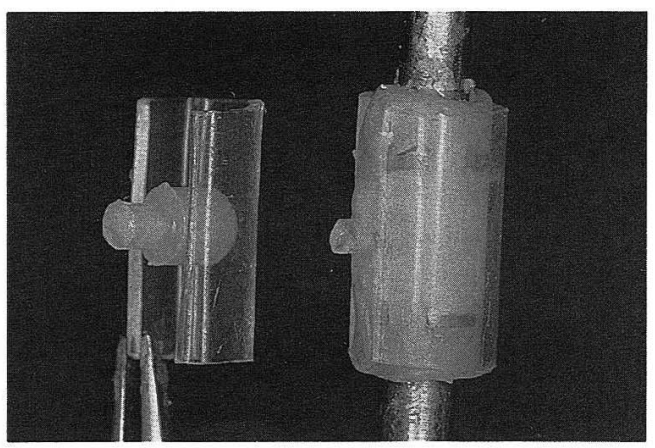

Fig. 4 The packing site of the composite resin in the device (right), and a slit of the teflon tube and the direction of the insert (left).
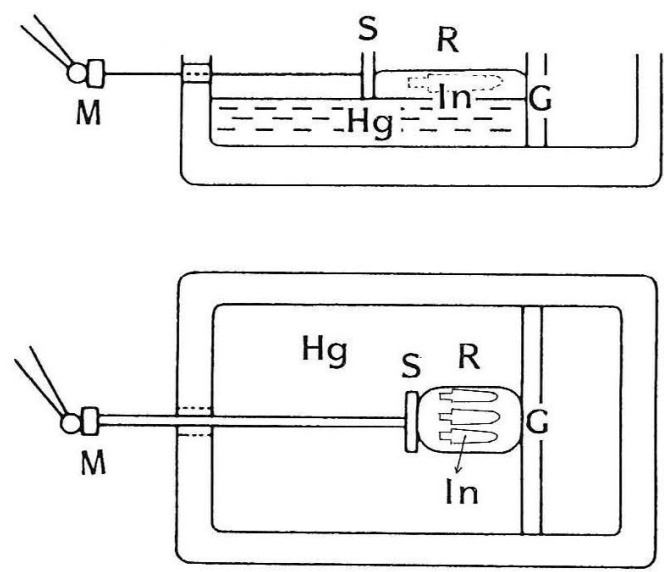

Fig. 5 Schematic illustration of the mercury bath for measuring of the polymerization shrinkage of composite resins. $\mathrm{R}=\mathrm{Com}-$ posite resin, $\mathrm{G}=$ Glass partition, $\mathrm{S}=$ Stainless steel plate, $\mathrm{M}=$ Magnet, $\mathrm{In}=\mathrm{BQCI}$ (Type T3). 
Autopolymerizing composite resin was attached to a partition in the mercury bath immediately after 20 -second mixing. The other end was attached to a stainless steel plate to measure shrinkage. Measurement was started 1 minute 30 second after the beginning of mixing, and polymerization shrinkage was measured at 10-second intervals for 90 minutes. The light-cured composite resin paste was placed in the mercury bath. After starting measurement, irradiation was uniformly performed using a visible light source for 5 minutes. Three parallel pieces of BQCI (Type T3) were inserted into the composite resin paste (Fig. 5). The $3 \mathrm{BQCI}$ accounted for $31-38 \%$ of the volume of the composite resin specimen. For comparison, measurement was also performed in specimens without BQCI. Three specimens were measured for each material and condition.

\section{RESULTS AND DISCUSSION}

The contraction stress 3 hours after hardening is shown in Table 2. Figure 6 shows the contraction stress 1 minute, 1 and 3 hours after starting measurement. Insertion of BQCI did not affect and rather slightly increased the contraction stress during polymerization of the composite resin. Though the amount of matrix involved in polymerization shrinkage was decreased by insertion of $\mathrm{BQCI}$, the composite resin may have strongly bound to the surface -treated BQCI and became stiff, resulting in a decrease in the flow that absorb contraction stress. CPP and P50 are highly loaded composite resins with an original filler content of 84 wt\% or more. Even after BQCI was inserted, the total filler content including BQCI was not markedly changed. Therefore, the contraction stress may have been affected only slightly. However, the filler of HMR is a microfiller with a filler content $62 \mathrm{wt} \%$. Insertion of BQCI may have increased the total filler content, also increasing polymerization contraction force. The elastic modulus may have increased with the increase of the filler content of the composite resin, and the contraction force may have increased with increases in the elastic modulus. Our results are in agreement with the results of Nemoto $e t a l^{7}$. In the specimens with an inserted teflon rod, contraction stress decreased with all materials. This may have been caused by detachment of the matrix resin on the interface, causing sliding.

The polymerization shrinkage was decreased by insertion of BQCI as shown in Table 3 . The changes in the polymerization shrinkage of each of the composite resins for 3 hours from

Table 2 Contraction stress 3 hours after starting of measurement of composite resins with/without $\mathrm{BQCI}(\mathrm{MPa})$

\begin{tabular}{lccc}
\hline \multicolumn{1}{c}{ Materials } & \multicolumn{2}{c}{ Glass ceramic inserts } & \\
\cline { 2 - 3 } \multicolumn{1}{c}{$(-)$} & $(+)$ & Dummy \\
\hline Clearfil Fll & $2.26(0.03)$ & $2.46(0.03)$ & $1.69(0.07)$ \\
Restolux SP-2 & $3.04(0.04)$ & $3.36(0.11)$ & $2.37(0.05)$ \\
P-50 & $3.52(0.21)$ & $3.45(0.04)$ & $3.17(0.12)$ \\
Clearfil Photo Posterior & $4.31(0.15)$ & $4.13(0.15)$ & $3.63(0.09)$ \\
Palfique Estelite & $3.22(0.08)$ & $3.21(0.64)$ & $2.38(0.16)$ \\
Heliomolar Radiopaque & $2.48(0.20)$ & $2.78(0.46)$ & $1.54(0.06)$ \\
\hline
\end{tabular}

* Teflon Rod

( ) Standard Deviation 
the beginning of polymerization are shown in Fig. 7-8. In particular, the decrease was 30$34 \%$ in $\mathrm{HMR}$ and $\mathrm{CF} 2$ with a relatively low filler content. Insertion of BQCI into composite resin effectively decreased the polymerization shrinkage but had only a slight effect on contraction stress during polymerization.
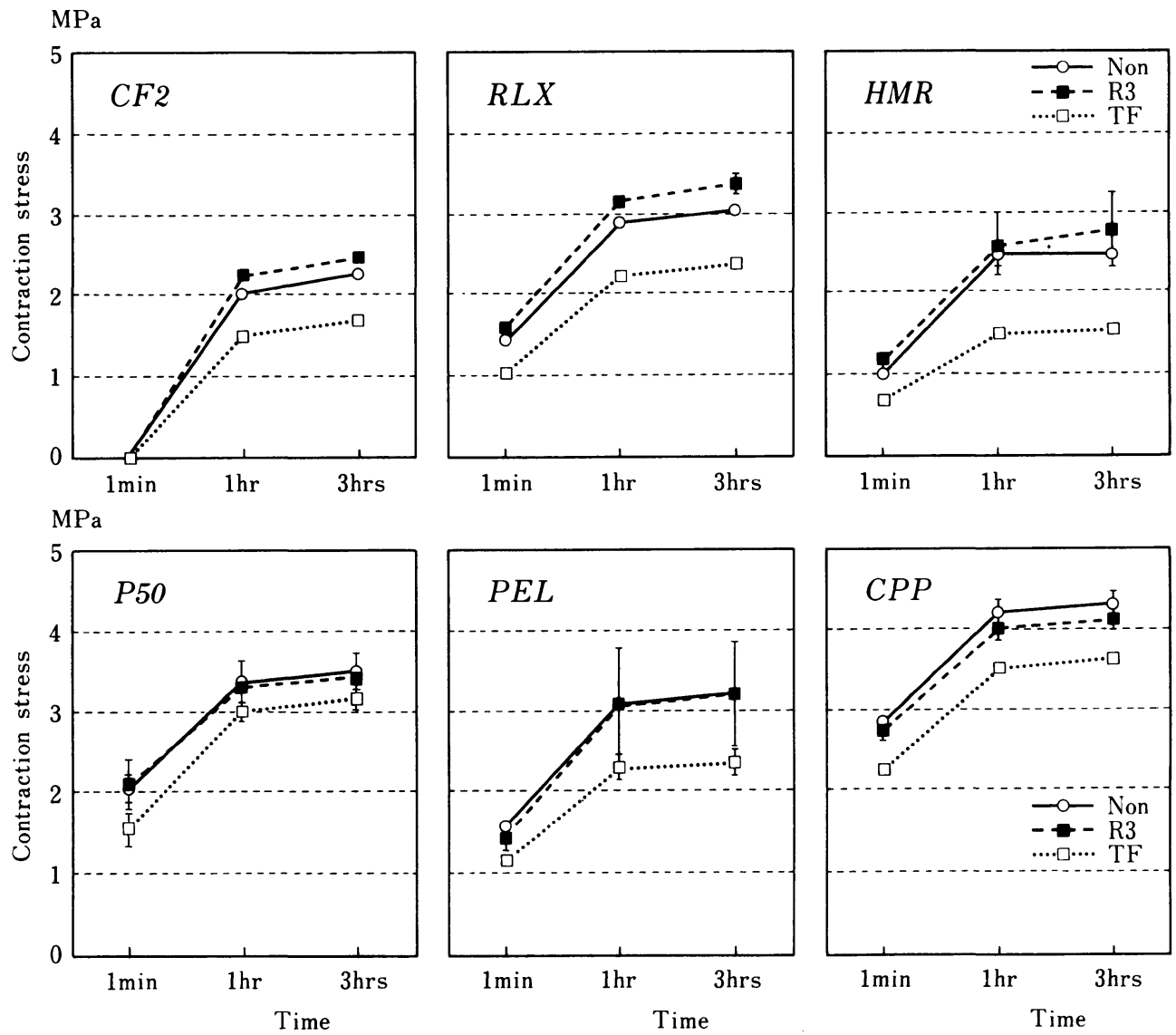

Fig. 6 Contraction stress 1 minute, 1 and 3 hours after start measurement.

Table 3 Polymerization shrinkage 90 minutes after strating of measurement of composite resins with / without BQCI

\begin{tabular}{lll}
\hline \multicolumn{1}{c}{ Materials } & \multicolumn{2}{c}{$\begin{array}{c}\text { Glass ceramic inserts } \\
(+)\end{array}$} \\
\hline Clearfil Fll & \multicolumn{1}{c}{$(+)$} \\
Restolux SP-2 & $0.81(0.20) \%$ & $0.57(0.06) \%$ \\
P-50 & $0.63(0.02)$ & $0.51(0.11)$ \\
Clearfil Photo Posterior & $0.40(0.01)$ & $0.39(0.03)$ \\
Palfique Estelite & $0.44(0.01)$ & $0.27(0.05)$ \\
Heliomolar Radiopaque & $0.55(0.04)$ & $0.50(0.01)$ \\
& $0.56(0.11)$ & $0.37(0.06)$ \\
\hline
\end{tabular}




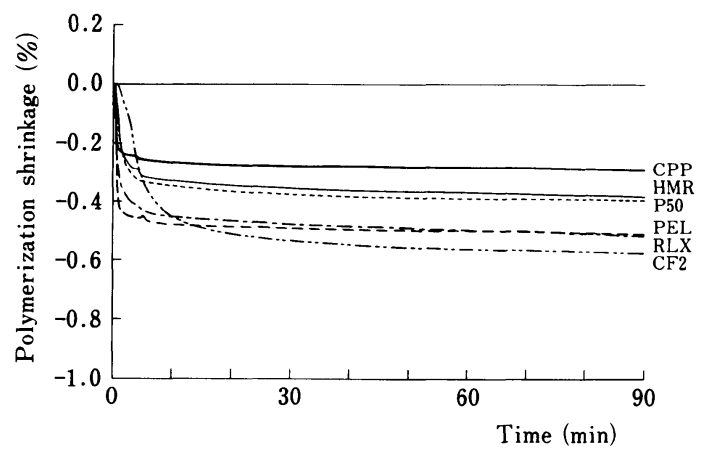

Fig. 7 Changes in the polymerization shrinkage of composite resins with $\mathrm{BQCI}$ inserted.

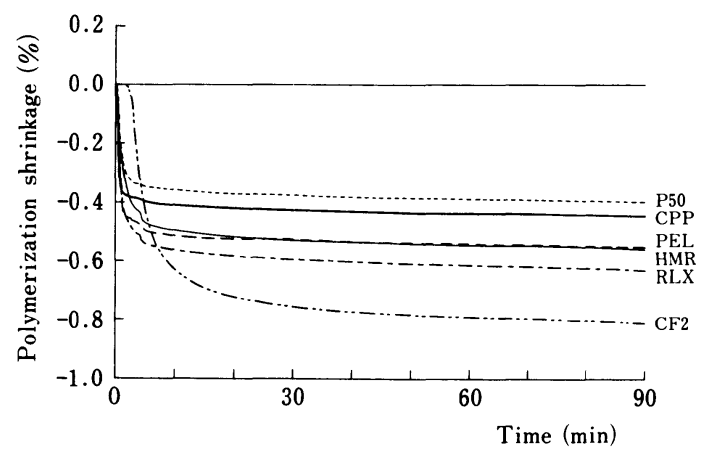

Fig. 8 Changes in the polymerization shrinkage of composite resins without $\mathrm{BQCI}$.

\section{CONCLUSION}

Contraction behavior of several composite resins inserted with $\beta$-Quartz Glass-Ceramic Inserts as "Megafillers" was determined in the study.

The results of this study suggest that $\beta$-Quartz Glass-Ceramic Insert was markedly effective in reducing polymerization shrinkage, but was not always effective in reducing contraction force during polymerization.

\section{REFERENCES}

1) Ishikawa, A.: Curing shrinkage and analysis on the composition of composite resins, Japan J Conserv Dent., 29: 129-170, 1986. (in Japanese)

2) Tani, Y. : Contraction force during polymerization of various composite resins, Dentistry in Japan, 26 : 97-100, 1989.

3) Bowen, R. L. and Setz, L. E. : Posterior composite restorations with a novel structure, $J$ Dent Res, 65 : $797,1986$.

4) Bowen, R. L. : Inserts for composite dental restorations, U. S. Patent 4,744,759, 1988.

5) Bowen, R. L., Eichmiller, F. C. and Misra, D. N. : Beta Quartz Microcrystalline Glass as Megafillers for Composites, J Dent Res, 68: 248, 1989. 
6) Donly, K. J., Wild, T. W., Bowen, R. L. and Jensen, M. E. : An in vitro investigation of the effects of glass inserts on the effective composite resin polymerization shrinkage, $J$ Dent Res, 68: 1234-1237, 1989.

7) Nemoto, K., Komatsu, K., Horie, K., Bowen, R. L., Tomotune, K., Ikemi, T. and Namiki, Y.: Shrinkage Stress of Composite Resin during Hardening. Part II The Effects of Filler Composition on the Shrinkage Stress, J J Dent Mater, 11 : 992-998, 1992. (in Japanese) 


\section{チタン鋳造体表面下の鋳巣 \\ 宮川 修, 渡辺孝一, 大川成剛, 中野周二, 本間七口, 小林正義 ${ }^{1}$ \\ 塩川延洋}

\section{新潟大学歯学部歯科理工学教室 \\ ${ }^{1}$ 新潟大学 $\mathrm{EMX}$ 室}

チタン鋳造体表面下の鋳巣の発生に関与する耐火物に ついて検討した. コンデンス法によって石英とクリスト バライト粉末，および両者とマグネシア粉末の混合物を 板状に成形し，高温で焼成した。この焼成板を鋳型とし て得た鋳造体の断面を光顕観察し, EPMAにより分析し た. 石英の場合は, 鋳込みはほぼ完全で, 反応層は典型 的な多層構造組織で, 鋳巣も少なかった. クリストバラ イトの場合はほとんどが鋳込み不良で, 網状の Ti-Si 相, クラック，および鋳巣からなる反応層が内部深くに広が
っていた. クリストバライトへのマグネシアの添加は鋳 込み性を顕著に改善し, 反応層も石英の場合に見られる 典型的な多層構造組織に変化した。しかし，鋳型壁の方 向に長細い鋳巣が $\alpha$ ケースの内側にほぼ等間隔に発生 し,あたりは Si と $\mathbf{M g}$ で污染されていた。これはフォル ステライトとチタンの反応によると考えられる. 石英と クリストバライトの反応性の違いを焼成強度と結びつけ ることはできなかった.

\section{Megafiller を充填したコンポジットレジンの重合収縮挙動}

谷 嘉明，南部敏之，石川明子 ${ }^{1}$, 勝山 茂 ${ }^{1}$

京都大学生体医療工学研究センター生体材料学研究部門

${ }^{1}$ 日本歯科大学歯科保存学教室第 II講座

Bowen は, 歯の窩洞に填入したコンポジットレジンペ ーストの中に $\beta$-Quartz Glass-Ceramic Insert の粗粒 を挿入するという新しい臨床技法, megafilled composite restoration を提案した. そこでわれわれは, glass insert を挿入したコンポジットレジンの重合収縮に与え る効果を重合収縮力およぴ重合収縮率の測定によって検 討した，実験に用いた材料は，常温重合型 1 種と光重合
型 5 種のコンポジットレジンである. 実験の結果, glass insert を挿入することによってコンポジットレジンの重 合収縮応力は変化しないか，むしろわずかながら大きく なる傾向を示した. 重合収縮率については, glass insert の挿入によって小さくなることがあきらかになった，な かでもフィラー充填率の比較的低いコンポジットレジン では，30〜34\%も小さくなることがわかった.

\section{咬合を考慮したクラウン製作のための CAD の改良について}

荘村泰治，高橋純造

大阪大学歯学部歯科理工学講座

前報で計測したデータに加え対合歯のバイトデータを 追加して, $\sqrt{6}$ 支台㐘のクラウン補綴のための形状をデザ インする CAD プロセスの改良を行った．まず歯冠デー 夕をバイトデータに対し中心咬合位になるように位置調 整した. 歯冠データを適正な位置に置いた後に対合歯の
FGP (機能咬合路) データによる咬合面の修正を行った. 歯冠端部とマージンを結合するために, 前報で用いた B ースプライン関数の代わりに放物線関数を用いた. その結 果，よりスムーズに連結した。このようにして支台歯デ ー夕，歯冠データおよび連結部データからなる $\mathrm{CAD}$ デ 